\title{
KANDUNGAN MERKURI DALAM CACING TANAH (Lumbricus Sp.) PADA SEDIMEN YANG TERCEMAR LOGAM BERAT
}

\section{MERCURY IN EARTHWORMS (Lumbricus Sp.) IN SEDIMENTS CONTAMINATED BY HEAVY METALS}

\author{
Irawati Mei Widiastuti ${ }^{1)}$, Diana Arfiati ${ }^{2)}$ \\ ${ }^{1)}$ Fakultas Peternakan dan Perikanan, Universitas Tadulako Palu \\ ${ }^{2)}$ Fakultas Perikanan dan Ilmu Kelautan, Universitas Brawijaya Malang \\ Email : irakarno@yahoo.com
}

\begin{abstract}
ABSTRAK
Merkuri $(\mathrm{Hg})$ adalah logam yang mempunyai toksisitas tinggi apabila terdapat dalam perairan. Cacing tanah merupakan salah satu organisme yang hidup di perairan tersebut. Tujuan penelitian untuk menentukan kandungan merkuri dalam sedimen dan cacing Lumbricus sp. yang hidup di perairan yang tercemar limbah dan menentukan parameter kualitas air di perairan yang tercemar limbah merkuri. Metode penelitian yang digunakan adalah survei. Sampel diambil pada saluran pembuangan limbah yang dibagi menjadi 4 titik pengambilan sampel. Metode Atomic Absorption Spectrophotometer (AAS) digunakan untuk mengukur konsentrasi merkuri ( $\mathrm{Hg}$ ) di sedimen dan cacing Lumbricus sp. Konsentrasi merkuri ( $\mathrm{Hg}$ ) di sedimen dan di cacing Lumbricus sp. tertinggi pada sampel yang diambil dari lokasi tepat saluran pembuangan limbah. Konsentrasi merkuri dalam sedimen dan cacing Lumbricus sp. berkorelasi positif. Konsentrasi $\mathrm{Hg}$ dalam cacing Lumbricus sp. meningkat seiring dengan meningkatnya konsentrasi $\mathrm{Hg}$ dalam sedimen. Derajad keasaman $(\mathrm{pH})$ dan TOM masih batas maksimum, sedangkan DO, BOD dan COD melebihi batas maksimum yang direkomendasikan.
\end{abstract}

Kata kunci : limbah, merkuri, Lumbricus sp.

\begin{abstract}
Mercury $(\mathrm{Hg})$ is a metal that has high toxicity if present in water. Earthworm is one of the organisms that live in it. The objective of the study was to determine the mercury content in the sediments and worms of Lumbricus sp. which live in polluted water and determine the parameters of water quality in waters contaminated by mercury waste. The research method used is survey method. Samples were taken on a sewage discharge divided into 4 sampling points. The Atomic Absorption Spectrophotometer (AAS) method is used to measure mercury concentration $(\mathrm{Hg})$ in sediments and Lumbricus sp worms. Concentrations of mercury $(\mathrm{Hg})$ in sediments and in worms Lumbricus sp. highest in samples taken from the exact location of sewage channels. Concentrations of mercury in sediments and worms Lumbricus sp. positively correlated. $\mathrm{Hg}$ concentration in worm Lumbricus sp. increased with increasing concentrations of $\mathrm{Hg}$ in the sediment. The degree of acidity $(\mathrm{pH})$ and TOM is still the recommended maximum, while DO, BOD and COD exceed the recommended maximum.
\end{abstract}

Keywords: waste, mercury, Lumbricus sp. 


\section{PENDAHULUAN}

Bahan pencemar berasal dari beberapa sumber termasuk limbah rumah tangga, industri dan pertanian. Bahan-bahan kimia inorganik termasuk logam, polutan organik, radioisotop dan obat-obatan menyebab kan perubahan lingkungan perairan terutama perubahan tingkah laku ikan dan kesehatan lingkungan perairan (Beitinger, 1990). Perairan yang terdapat di sepanjang Desa Kejapanan Kecamatan Gempol Kabupaten Pasuruan merupakan aliran sungai yang dilewati oleh limbah yang mengandung merkuri yang dibuang oleh industri di sekitarnya. Merkuri $(\mathrm{Hg})$ adalah logam yang mempunyai toksisitas tinggi apabila terdapat dalam perairan. Merkuri juga terakumulasi dalam sedimen dan menyebar lewat rantai makanan. Merkuri sangat berbahaya karena merkuri diabsorbsi oleh organisme dan terakumulasi di dalam tubuh (Siregar, et al., 2012).

Cacing tanah merupakan salah satu organisme yang hidup di perairan tersebut. Cacing tanah erat hubungan nya dengan kondisi lingkungan dimana cacing tersebut hidup. Lingku ngan tersebut meliputi kondisi fisik, kimia, biologi dan ketersediaan makanan. Faktor ekologis yang sangat mempengaruhi kehidupan cacing tanah adalah $\mathrm{pH}$, kelembaban, aerasi dan $\mathrm{CO}_{2}$, bahan organik, jenis dan suplai nutrisi (Hanafiah, 2003).

Pada penelitian ini, organisme yang digunakan sebagai agen penyerap merkuri pada limbah pengolahan emas adalah cacing tanah (Lumbricus sp.) dengan pertimbangan bahwa cacing tanah memiliki toleransi yang tinggi terhadap kontaminasi logam berat dan mampu mengakumulasi logam berat dalam jaringannya. Selain itu, cacing tanah dapat digunakan sebagai bioindikator pencemaran tanah (Zhang, et al, 2009), indikator kualitas dan kesehatan tanah (Edwards, 2004) karena cacing tanah berperan penting pada dekomposisi materi organik dan perputaran nutrien. Cacing tanah dapat digunakan sebagai organisme indikator untuk mengetahui pengaruh biologi dari polutan (Spurgeon, et al., 2003).

Penelitian tentang cacing tanah yang telah dilakukan di daerah pertambangan emas di Kalimantan. Hasil penelitian menunjukkan bahwa cacing tanah yang berada di sekitar areal pertambangan emas dan areal bekas pertambangan emas di Kecamatan Cempaka Kota Banjarbaru Kalimantan 
Selatan, mengandung merkuri sebesar 180-265 ppb. Nilai tersebut lebih tinggi dibandingkan dengan kadar merkuri di tanah (4,0-6,5 ppb). Hal ini menunjukkan bahwa cacing tanah mampu mengikat dan mengakumulasi logam berat di dalam tubuhnya melalui kontak langsung dengan media tanah dan makanannya yang mengandung merkuri (Widi, 2014). Berdasarkan pada hasil penelitian yang telah dilakukan maka perlu diketahui keterkaitan antara merkuri yang diserap oleh cacing tanah dengan kandungan merkuri pada sedimen.

Tujuan penelitian adalah menentukan kandungan merkuri dalam sedimen dan cacing Lumbricus sp. yang hidup di perairan yang tercemar limbah merkuri dan menentukan parameter kualitas air di perairan yang tercemar limbah merkuri.

\section{METODE PENELITIAN}

\section{Waktu dan Tempat}

Penelitian dilaksanakan selama enam bulan (Januari - Maret 2017) di Kecamatan Gempol Kabupaten Pasuruan. Metode penelitian yang digunakan adalah metode survei. Lokasi pengambilan sampel ditentukan secara purposive sampling (sebelum saluran pembuangan limbah (S1), tepat di saluran pembuangan limbah (S2) dan setelah saluran pembuangan limbah (S3 dan S4)).

\section{Bahan dan Parameter}

Sampel yang diuji adalah sampel air, sedimen dan cacing Lumbricus sp. Sampel air diambil secara langsung dan disimpan dalam botol sampel. Sampel sedimen diambil menggunakan pipa paralon, disimpan dalam wadah dan dibawa ke laboratorium untuk diukur konsentrasi merkuri dan ditentukan teksturnya. Sampel cacing tanah yang diambil dalam penelitian ini adalah cacing berukuran $5-10 \mathrm{~cm}$ yang terdapat pada sedimen. Cacing tanah diambil secara langsung dengan substratnya, disimpan dalam wadah dan diukur kandungan merkurinya. Parameter fisika-kimia perairan yang diukur dalam penelitian ini adalah suhu, derajat keasaman $(\mathrm{pH})$, dissolved oxygen (DO), biological oxygen demand (BOD), chemical oxygen demand (COD) perairan dan total organic matter (TOM). 


\section{Prosedur kerja}

a. Preparasi sampel cacing tanah

Preparasi sampel cacing tanah dimulai dengan mengambil sampel dan ditimbang, kemudian dioven hingga suhu $300^{\circ} \mathrm{C}$. Sampel yang sudah dioven didinginkan, dan ditambahkan larutan $\quad \mathrm{HNO}_{3} \quad 6,5 \%$ sebanyak $10 \mathrm{ml}$, kemudian sampel dipanaskan selama 5 menit dan diaduk sampai homogen. Setelah itu, sampel disaring menggunakan kertas saring lalu dicampurkan aquades sampai larutan mencapai $50 \mathrm{ml}$. Hasil akhir pengujianh sampel diukur dengan menggunakan AAS.

\section{b. Preparasi sampel sedimen}

Preparasi sampel sedimen dimulai dengan memisahkan sedimen dengan serasah, cangkang kerang, kemudian contoh sedimen dikeringkan dalam oven pada suhu $105^{\circ} \mathrm{C}$ selama 3 jam. Sedimen yang telah dioven kemudian dihaluskan dan ditimbang sebanyak 1 gram dan dimasukkan ke dalam gelas piala untuk selanjutnya ditambahkan $\mathrm{HNO}_{3}$ dan $\mathrm{H}_{2} \mathrm{SO}_{4}$. Setelah itu ditambahkan $20 \mathrm{ml}$ campuran $\mathrm{HNO}_{3} / \mathrm{HCl}$ dan didestruksi selama 3 jam pada suhu $120^{\circ} \mathrm{C}$. Hasil destruksi disaring dan filtratnya ditampung dalam labu ukur $50 \mathrm{ml}$ dan diencerkan dengan aquades. Filtrat yang telah dihasilkan kemudian diukur dengan AAS (APHA, 2010).

\section{Analisis data}

Data hasil pengukuran kandungan $\mathrm{Hg}$ dalam cacing tanah dan sedimen ditabulasikan dalam bentuk tabel dan grafik untuk selanjutnya dibahas secara deskriptif. Untuk membuktikan bahwa kandungan merkuri dalam cacing tanah akan meningkat apabila logam berat dalam sedimen juga meningkat, digunakan uji statistik analisis regresi linier sederhana.

$$
\mathrm{Y}=\mathrm{a}+\mathrm{bX}
$$

Keterangan :

$\mathrm{Y}=$ konsentrasi logam berat dalam tubuh cacing tanah (ppm);

$\mathrm{X}=$ konsentrasi logam berat pada sedimen (ppm); a dan $\mathrm{b}=$ konstanta

Untuk melihat kondisi pencemaran pada perairan Desa Kejapanan Kecamatan Gempol Kabupaten Pasuruan, hasil analisis logam berat dibandingkan dengan Kriteria Baku Mutu Air berdasarkan kelas (PP No. 82 tahun 2001 tentang Pengelolaan Kualitas Air dan Pengendalian Pence maran) (Tabel 1). 
Sedangkan untuk melihat kondisi digunakan baku mutu standar kualitas pencemaran logam berat di sedimen, IADC/CEDA (1997) (Tabel 2).

Tabel 1. Kriteria Baku Mutu Air Berdasarkan Kelas

\begin{tabular}{cc}
\hline Parameter & PP No. 82 Tahun 2001 \\
\hline Derajat keasaman $(\mathrm{pH})$ & Kelas I - III $: 6-9 ;$ Kelas IV $: 5-9$ \\
BOD $(\mathrm{mg} / \mathrm{L})$ & Kelas I $: 2 ;$ II $: 3 ;$ III $: 6 ;$ IV $: 12$ \\
COD $(\mathrm{mg} / \mathrm{L})$ & Kelas I $: 10 ;$ II $: 25 ;$ III $: 50 ;$ IV $: 100$ \\
DO $(\mathrm{mg} / \mathrm{L})$ & Kelas I $: 6 ;$ II $: 4 ;$ III $: 3 ;$ IV $: 0$ \\
Merkuri $(\mathrm{Hg})(\mathrm{mg} / \mathrm{L})$ & Kelas I $: 0,001 ;$ II dan III $: 0,002 ;$ IV $: 0,005$ \\
Residu Terlarut $(\mathrm{mg} / \mathrm{L})$ & Kelas I - III $: 1000 ;$ IV $: 2000$ \\
Residu tersuspensi $(\mathrm{mg} / \mathrm{L})$ & Kelas I dan II $: 50 ;$ III dan IV $: 400$ \\
\hline Sumber $:$ Peraturan Pemerintah No. 82 Tahun 2001
\end{tabular}

Tabel 2. Baku Mutu Konsentrasi Logam Berat dalam Sedimen

\begin{tabular}{cccccc}
\hline Logam berat & Level target & Level limit & Level tes & Level intervensi & $\begin{array}{c}\text { Level } \\
\text { bahaya }\end{array}$ \\
\hline $\begin{array}{c}\text { Merkuri (Hg) } \\
(\mathrm{ppm})\end{array}$ & 0,3 & 0,5 & 1,6 & 10 & 15 \\
\hline Sumber : IADC/CEDA (1997) & & & &
\end{tabular}

Keterangan : konsentrasi dalam ppm

1. Level target : jika konsentrasi kontaminan pada sedimen memiliki nilai lebih kecil dari nilai level target, kontaminan pada sedimen tidak terlalu berbahaya bagi lingkungan.

2. Level limit : jika konsentrasi kontaminan pada sedimen memiliki nilai maksimum yang dapat ditolelir bagi kesehatan manusia maupun ekosistem.

3. Level tes : jika konsentrasi kontaminan pada sedimen pada kisaran nilai antara level limit dan level tes (tercemar ringan)

4. Level intervensi : jika konsentrasi kontaminan pada sedimen berada pada kisaran nilai level tes dan level intervensi (tercemar sedang).

5. Level bahaya : jika konsentrasi kontaminan pada sedimen nilainya lebih besar dari baku mutu level bahaya, harus segera dilakukan pembersihan sedimen.

\section{HASIL DAN PEMBAHASAN}

\section{HASIL}

\section{Konsentrasi Merkuri (Hg) di Sedimen dan Cacing Lumbricus sp.}

Hasil penelitian menunjukkan bahwa konsentrasi merkuri sampel S2, baik yang terkandung di sedimen maupun dalam cacing Lumbricus sp., lebih tinggi dibandingkan dengan sampel S1, S3 dan S4. Konsentrasi merkuri pada sampel 3 dan sampel 4 lebih rendah daripada sampel 1 . Konsentrasi merkuri dalam sedimen tertinggi pada sampel 2 sebesar 0,29 $\pm 0,006 \mathrm{mg} / \mathrm{L}$, sedangkan konsentrasi merkuri paling rendah pada sampel 4 $(0,147 \pm 0,007 \quad \mathrm{mg} / \mathrm{L})$. Gambar 1 menunjukkan bahwa konsentrasi 
merkuri di sedimen lebih tinggi Lumbricus sp.

daripada konsentrasi merkuri di cacing

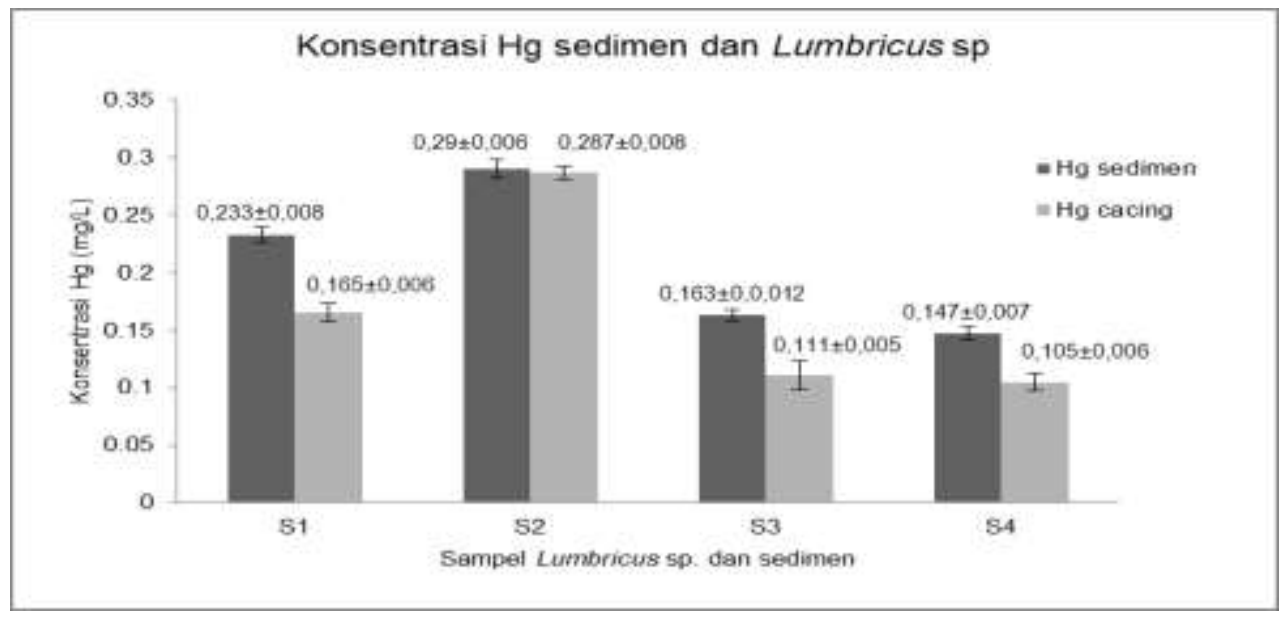

Gambar 1. Konsentrasi Hg pada Lumbricus sp. dan sedimen

Merkuri di sedimen berkorelasi positif terhadap konsentrasi merkuri di cacing Tubifex, dengan persamaan $\mathrm{Y}=1,2289 \mathrm{X}-0,0889$ dan nilai $\mathrm{R}^{2}=$ 0,9248. Hal ini menunjukkan bahwa konsentrasi merkuri di sedimen memberikan kontribusi terhadap pening- katan konsentrasi merkuri di cacing Tubifex sebesar 96,17\% (Gambar 2). Peningkatan konsentrasi merkuri dalam sedimen akan meningkatkan konsentrasi merkuri dalam cacing Lumbricus sp. (Gambar 2).

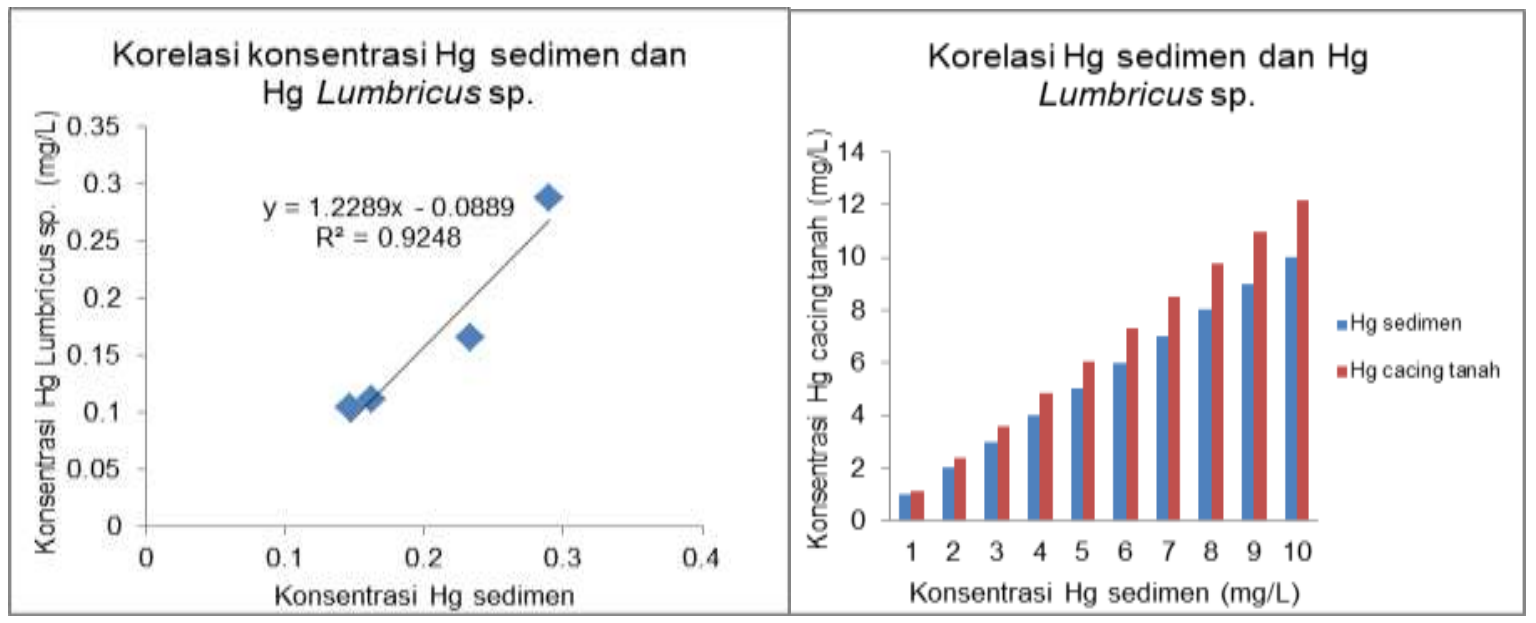

Gambar 2. Korelasi konsentrasi $\mathrm{Hg}$ sedimen dan $\mathrm{Hg}$ cacing Lumbricus sp. 


\section{Parameter Lingkungan Perairan}

Parameter lingkungan perairan yang diamati pada penelitian ini meliputi parameter suhu, derajat keasaman $(\mathrm{pH})$, dissolved oxygen (DO), biological oxygen demand (BOD), chemical oxygen demand (COD) perairan dan total organic matter (TOM). Pengukuran parameter lingkungan penting dilakukan karena sangat mempengaruhi kehidupan organisme secara fisiologi. Faktorfaktor yang mempengaruhi laju absorbsi logam berat di perairan antar lain suhu, $\mathrm{pH}$, oksigen terlarut, fraksi sedimen, adanya senyawa lain dan ukuran organisme (Darmono, 1995). Hasil pengukuran parameter lingkungan di perairan Desa Kejapanan Kecamatan Gempol Kabupaten Pasuruan tertera pada Tabel 3.

Tabel 3. Parameter lingkungan pada masing-masing sampel

\begin{tabular}{llllllc}
\hline Sampel & $\mathrm{pH}$ & Suhu $\left({ }^{\circ} \mathrm{C}\right)$ & $\mathrm{DO}(\mathrm{mg} / \mathrm{L})$ & $\mathrm{COD}(\mathrm{mg} / \mathrm{L})$ & $\mathrm{BOD}(\mathrm{mg} / \mathrm{L})$ & TOM $(\mathrm{mg} / \mathrm{L})$ \\
\hline $\mathrm{S} 1$ & $7,36 \pm 0,046$ & $29,50 \pm 0,173$ & $7,25 \pm 0,035$ & $181,67 \pm 3,055$ & $134,33 \pm 3,055$ & $87,04 \pm 0,970$ \\
\hline $\mathrm{S} 2$ & $7,37 \pm 0,058$ & $29,20 \pm 0,100$ & $7,03 \pm 0,010$ & $163,67 \pm 3,512$ & $157,67 \pm 1,528$ & $107,80 \pm 2,330$ \\
\hline $\mathrm{S} 3$ & $7,06 \pm 0,040$ & $29,77 \pm 0,208$ & $7,50 \pm 0,100$ & $194,67 \pm 2,517$ & $112,00 \pm 2,646$ & $128,45 \pm 0,601$ \\
\hline S4 & $7,10 \pm 0,100$ & $29,20 \pm 0,100$ & $7,01 \pm 0,015$ & $182,33 \pm 3,215$ & $108,67 \pm 1,528$ & $117,34 \pm 1,574$ \\
\hline
\end{tabular}

Tabel 3 menunjukkan bahwa $\mathrm{pH}$ dan BOD tertinggi pada $\mathrm{S} 2$, sedangkan suhu, DO, COD dan TOM tertinggi pada S3. Apabila dilihat dari Gambar 3 terlihat bahwa apabila suhu air tinggi maka $\mathrm{pH}$ air rendah, DO, COD dan TOM tinggi namun
BOD rendah. Apabila merujuk dari PP 82 Tahun 2001, maka nilai $\mathrm{pH}$ dan TOM masih batas maksimum yang direkomendasikan sedangkan DO, BOD dan COD melebihi batas maksimum yang direkomendasikan.

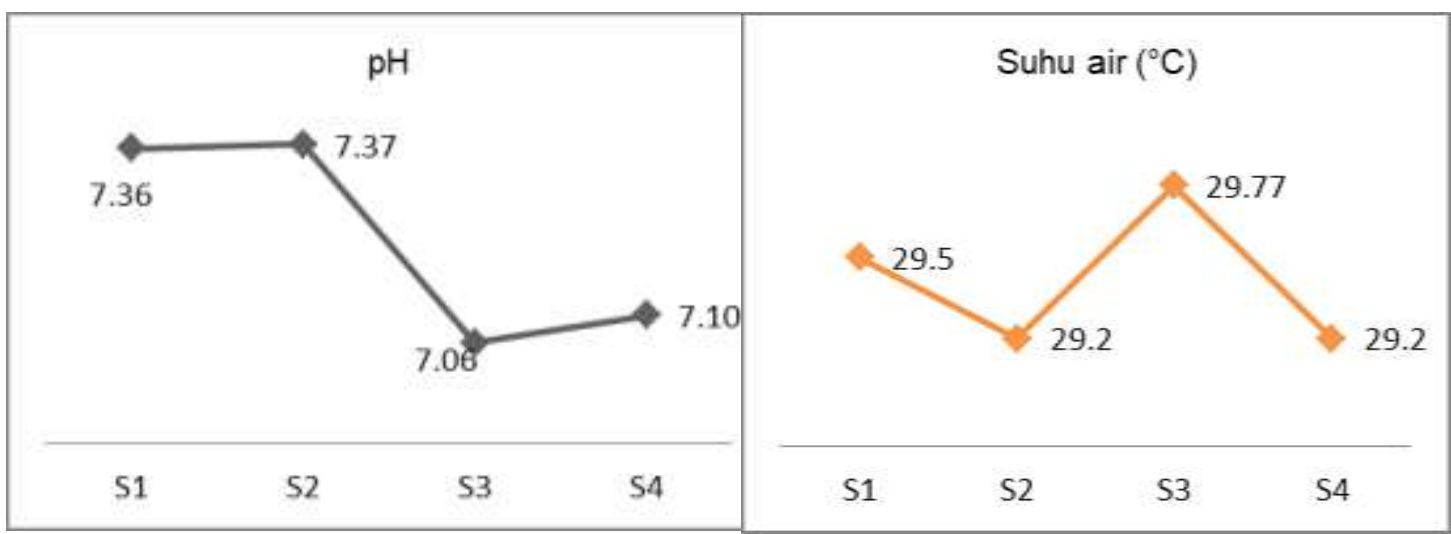




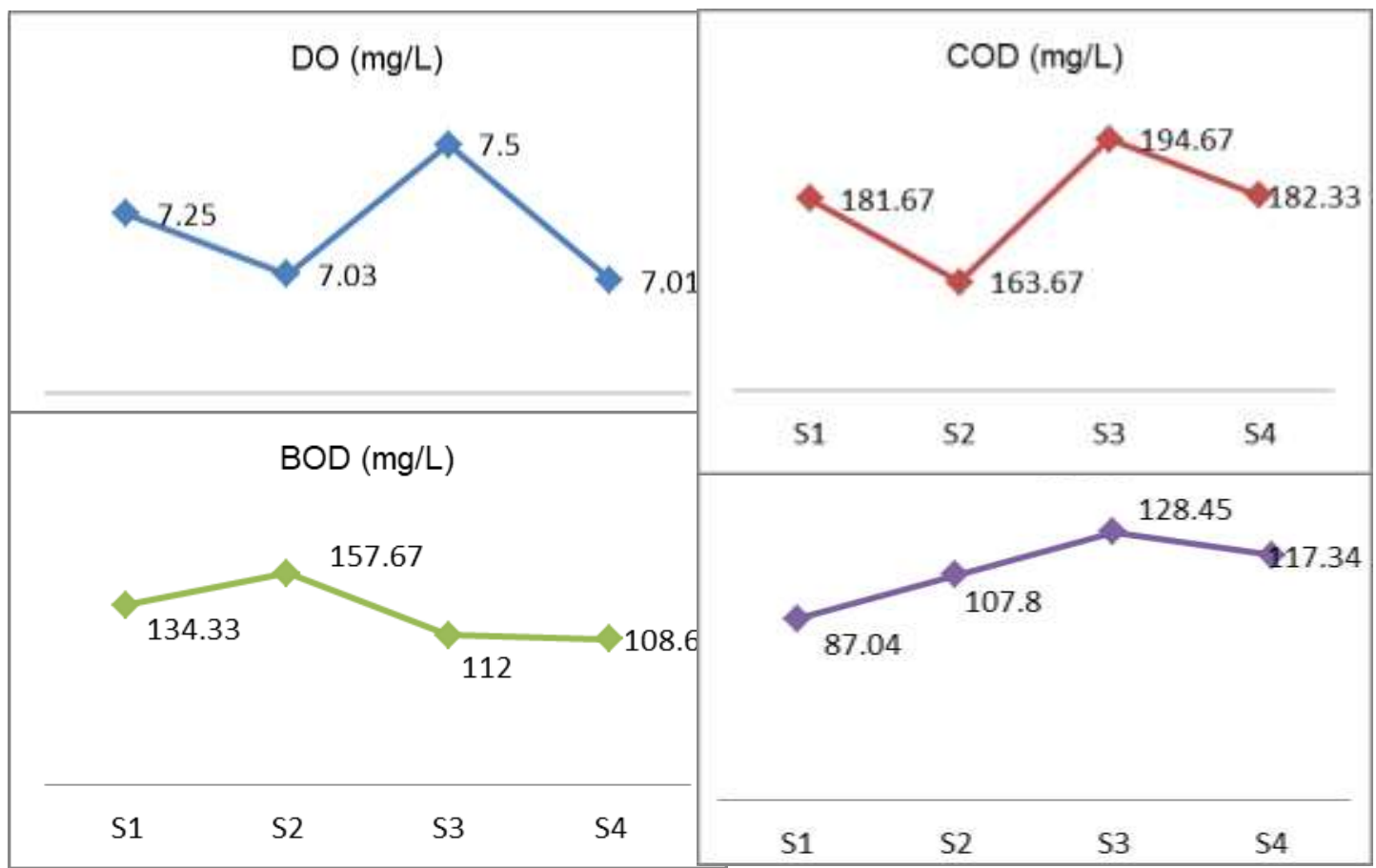

Gambar 3. Parameter fisika-kimia perairan

PEMBAHASAN

\section{Konsentrasi merkuri di sedimen dan cacing Lumbricus sp.}

Konsentrasi merkuri yang terdapat di sedimen dan cacing Lumbricus sp. tertinggi pada sampel 2 (S2), hal ini disebabkan sampel 2 (S2) merupakan sampel yang diambil pada lokasi tepat saluran pembuangan limbah. Limbah merkuri akan terikut aliran air sehingga pada sampel 3 dan sampel 4 yang diambil pada lokasi setelah saluran pembuangan limbah, mengandung merkuri yang lebih rendah daripada sampel 2. Apabila merujuk pada baku mutu konsentrasi logam berat dalam sedimen (IADC/CEDA, 1997), maka konsentrasi merkuri dalam sedimen masih pada level target $(0,3 \mathrm{ppm})$. Hal ini menunjukkan bahwa jika konsentrasi kontaminan pada sedimen memiliki nilai lebih kecil dari nilai level target, kontaminan pada sedimen tidak terlalu berbahaya bagi lingkungan. Besar kecilnya kandungan merkuri disebabkan adanya fluktuasi aktivitas penambangan, pengolahan dan iklim/cuaca. Tingkat mobilitas merkuri tergantung pada musim dan jarak, apabila arus besar maka merkuri terbawa oleh arus lebih jauh dari sumber pencemar. 
Semakin jauh dari pengolahan bijih emas maka penyebaran merkuri juga semakin kecil (Widodo, 2008).

Jumlah logam berat yang terkandung di dalam sedimen menunjukkan tingkat pencemaran air. Logam berat yang masuk ke dalam perairan akan mengalami pengendapan, pengenceran dan dispersi, kemudian diserap oleh organisme yang hidup di perairan tersebut (Chen, et al., 2012). Logam berat mempunyai sifat mudah mengikat dan mengendap di dasar perairan dan bersatu dengan sedimen (Harahap, 1991).

Merkuri di sedimen berkorelasi positif terhadap konsentrasi merkuri di cacing. Peningkatan konsentrasi merkuri dalam sedimen akan meningkatkan konsentrasi merkuri dalam cacing Lumbricus sp. Cacing tanah melakukan proses pertukaran gas melalui kulit, sehingga apabila di lingkungannya terdapat bahan pencemar akan ikut terabsorbsi dan terakumulasi di dalam tubuh cacing tanah. Cacing tanah dapat menyerap logam berat melewati kulitnya atau dengan mengkonsumsi air, makanan tercemar dan/atau partikel tanah (Lanno et al, 2004 dalam Hobbalen et al, 2006). Senyawa merkuri bersifat toksik pada ikan dan biota akuatik lainnya karena merkuri dapat mengalami biomagnifikasi pada rantai makanan. Organisme yang berada pada tingkat tropik yang paling tinggi memiliki konsentrasi merkuri yang lebih tinggi daripada organisme pada tingkat tropik rendah (Effendi, 2000).

Konsentrasi merkuri dalam cacing tanah meningkat dengan meningkatnya konsentrasi merkuri dalam sedimen, hal ini berkaitan dengan habitat cacing tanah yang hidup di sedimen pada perairan. Cacing tanah sangat sensitif terhadap sinar matahari, cahaya maupun bahan kimia dalam lingkungannya, baik logam berat maupun bahan organik (Zhang et al, 2009). Efek logam berat pada organisme tergantung pada konsentrasi dan lamanya paparan. (Lanno et al, 2004 dalam Hobbalen, et al, 2006). Selain itu, berkaitan pula dengan sifat merkuri yang bioakumulatif dan tidak bisa terurai sehingga dalam jangka waktu tertentu merkuri terakumulasi di dalam tubuh cacing tanah. Merkuri menimbulkan resiko ekotoksikologi terhadap invertebrata seperti cacing tanah. Masih sedikit diketahui tentang jalur penyerapan $\mathrm{Hg}$ oleh cacing tanah 
(Lock dan Janssen, 2001 dalam Zagury, et al., 2006). Namun serapan logam pada umumnya dapat terjadi melalui jalur yang berbeda seperti penyerapan pasif melalui membran dermal dari logam terlarut ke dalam air pori tanah, selain itu juga melalui pemasukan larutan logam tanah yang tercemar dan/atau konsumsi partikel tanah yang terkontaminasi (Arnold, et al., 2003 dalam Zagury et al., 2006).

\section{Parameter kualitas air}

Tabel 3 menunjukkan bahwa $\mathrm{pH}$ dan BOD tertinggi pada S2, sedangkan suhu, DO, COD dan TOM tertinggi pada S3, hal ini disebabkan Apabila dilihat dari Gambar 3, suhu air tinggi maka $\mathrm{pH}$ air dan BOD rendah sedangkan DO, COD dan TOM tinggi. Apabila merujuk dari PP 82 Tahun 2001, maka nilai $\mathrm{pH}$ dan TOM masih batas maksimum yang direkomendasikan, sedangkan DO, BOD dan COD melebihi batas maksimum yang direkomendasikan. Apabila dikaitkan dengan konsentrasi merkuri yang ada di sedimen dan merkuri pada cacing tanah, maka pada saat DO dan COD tinggi, konsentrasi merkuri juga meningkat, sedangkan pada saat BOD rendah, konsentrasi merkuri tinggi. Kebutuhan oksigen pada cacing cukup tinggi, sedangkan karbondioksida dalam tubuh cacing apabila tidak diekskresikan akan meracuni tubuh (Effendi, 2000).

Faktor-faktor yang mempengaruhi toksisitas merkuri terhadap organisme akuatik adalah suhu, $\mathrm{pH}$, salinitas, DO dan alkalinitas. Organis me mempunyai daya adaptasi yang berbeda-beda terhadap suhu. Adaptasi ikan terhadap suhu tergantung pada spesies, stadia pertumbuhan, aklimati sasi, DO, jenis dan tingkat pencemaran, lamanya lingkungan terpapar panas dan musim. Suhu yang relatif tinggi menyebabkan ikan naik ke permukaan untuk mendapatkan oksigen sehingga kecepatan respirasi nya meningkat dan akan mengakibat kan kematian ikan (Withgott, 2007).

Derajat keasaman $(\mathrm{pH})$ menunjukkan bahwa peningkatan $\mathrm{pH}$ menyebabkan peningkatan toksisitas. Hal ini merupakan akibat menurunnya kompetisi antara ion $\mathrm{Cd}, \mathrm{Pb}$ maupun $\mathrm{Hg}$ dengan ion-ion hidrogen seiring naiknya pH (Babich and Stozky, 2001; Argawala, 2006). Oksigen terlarut (DO) merupakan parameter mutu air 
yang sangat penting karena nilai oksigen terlarut dapat menunjukkan tingkat pencemaran di perairan.

\section{KESIMPULAN}

Konsentrasi merkuri (Hg) di sedimen dan di cacing Lumbricus sp. tertinggi pada sampel yang diambil dari lokasi yang berada tepat pada saluran pembuangan limbah. Konsentrasi merkuri dalam sedimen dan cacing Lumbricus sp. berkorelasi positif. Konsentrasi $\mathrm{Hg}$ dalam cacing Lumbricus sp. meningkat seiring dengan meningkatnya konsentrasi $\mathrm{Hg}$ dalam sedimen. Derajad keasaman (pH) dan TOM masih batas maksimum, sedangkan DO, BOD dan COD melebihi batas maksimum yang direkomendasikan.

\section{DAFTAR PUSTAKA}

APHA American Public Health Association. 2010. Standard Methods for The Examination of Water and Waste Water 22th Edition. APHA.AWWA.WPOF. Washington DC.

Beitinger, T.L. 1990. Behavioural Reactions for Assessment of Stress in Fishes. J. Great Lakes Res. 16, 495-528.

Chen, C.W., C.F. Chen, and C.D. Dong. 2012. Contamination and Potential Ecological of Mercury in Sediments of Kaohsiung River Mouth. Taiwan. International Journal of Environmental Science and Development. 3(1): 66-71.

Darmono, 1995. Logam dalam Sistem Biologi Makhluk Hidup. Universitas Indonesia. Jakarta. p 139.

Edward, J.W., K,S., Edyvane, V.A., Boxall, M., Hamann and K.I., Soole. 2001. Metal Levels in Seston and Marine Fish Flesh Near Industrial and Metropolitan Centres in South Australia. Mar. Pollut. Bull. 26 (2001): 389-396.

Effendi, H. 2000. Telaahan Kualitas Air. Jurusan Manajemen Sumberdaya Perairan Fakultas Perikanan dan Ilmu Kelautan. IPB Bogor.

Hanafiah, 2003. Biologi Tanah. PT. Raja Grafindo Persada. Jakarta.

Harahap, S. 1991. Tingkat Pencemaran Air Kali Cakung Ditinjau dari Sifat Fisika-Kimia Khususnya Logam Berat dan Keanekaragaman Jenis Bentos Makro. IPB. 167.

Hobbelen, PHF., J.E. Koolhaas, C.A.M. Van Gestel. 2006. Bioaccumulation of Heavy metals in Earthworms Lumbricus rubellus and Aporrectodea caliginosa in Relation to Total and Available Metal Concentration in Field Ions. Environmental Pollution. 144 (2006): 639-646.

International Association of Draging Companies/Central Dreging 
Association (IACD/CEDA), 1997. Convension, Codes and Conditions: Marine Disposal Environmental Aspect Dredging.

Peraturan Pemerintah Nomor 80 Tahun 2001 tentang Pengelolaan Kualitas Air dan Pengendalian Pencemaran.

Siregar, YI., A. Zamri, dan H. Putra. 2012. Penyerapan Timbal $(\mathrm{Pb})$ pada Sistem Organ Ikan Mas (Cyprinus carpio L.). Jurnal Ilmu Lingkungan.

Spurgeon, D.J., S. Claus, J.L. Linsay, K.H. Peter, and K. Peter. 2005. Earthworm Responses to $\mathrm{Cd}$ and $\mathrm{Cu}$ under Fluctuating Environmental Conditions: Comparison With Results from Laboratory Exposures. Environmental Pollution J. 136 (2005) 443-452. doi: 10.1016/j.encpol.2005.01.013.

Whitgott, J., and S. Brennan. 2007. Environment: The Science Behind the Stories. San Fransisco: Pearson Benjamin Cummings.

Widi, S.A.P. 2014. Ekspresi Heat Shock Protein (HSP) pada Cacing Tanah (Lumbricus Sp.) di Areal Pertambangan Emas. Thesis. Fakultas Perikanan dan Ilmu Kelautan Universitas Brawijaya. Malang.

Widodo. 2008. Pencemaran Air Raksa (Hg) sebagai Dampak
Pengolahan Bijih Emas di Sungai Ciliunggunung, Waluran, Kab. Sukabumi. Jurnal Geologi Indonesia. 3 (3): 139-149.

Zagury, GJ., C.M. Neculita, C. Basten, L. Deschenes. 2006. Mercury Fractination, Bioavailability and Ecotoxicity in Highly Contamina ted Soils From Chlor-Alkali Plants. Environmental Toxicology and Chemistry. 25(4): 1138-1147.

Zhang, ZS., D.M. Zheng, Q.C. Wang, and X.L. Guo. 2009. Bioaccumulation of Total and Methyl Mercury in Three Earthworm Species (Drawida sp., Allolobophora sp. and Limnodrillus sp.) Bull Enviroron Contam Toxicol. 83: 937-942. 